Research Article

\title{
Geopolymers Based on Phosphoric Acid and Illito-Kaolinitic Clay
}

\author{
S. Louati, S. Baklouti, and B. Samet \\ Laboratoire de Chimie Industrielle, Ecole Nationale d'Ingénieurs de Sfax, Université de Sfax, BP. W3038, Tunisia \\ Correspondence should be addressed to B. Samet; sametbasma@yahoo.fr
}

Received 19 April 2016; Accepted 17 July 2016

Academic Editor: Luigi Nicolais

Copyright ( 92016 S. Louati et al. This is an open access article distributed under the Creative Commons Attribution License, which permits unrestricted use, distribution, and reproduction in any medium, provided the original work is properly cited.

\begin{abstract}
New three-dimensional geopolymer materials based on illito-kaolinitic clay and phosphoric acid were synthesized. The effect of $\mathrm{Si} / \mathrm{P}$ molar ratio on the geopolymers properties was studied. Raw, calcined clay, and geopolymers structures were investigated using XRD, IR spectroscopy, and SEM. The phosphoric acid-based geopolymers mechanical properties were evaluated by measuring the compressive strength. The Si/P molar ratio was found to increase with the increase of the compressive strength of the obtained geopolymers, which attained a maximum value at $\mathrm{Si} / \mathrm{P}$ equal to 2.75 . Beyond this ratio, the mechanical strength decreases. The XRD patterns of these geopolymers samples have proven that when the $\mathrm{Si} / \mathrm{P}$ molar ratio decreases, the amorphous phase content increases. Besides, the structural analyses have revealed the presence of aluminum phosphate and Si-O-Al-O-P polymeric structure, whatever the Si/P molar ratio is (between 2.25 and 3.5). The obtained results have confirmed that the presence of the associated minerals such as hematite and quartz in the clay does not prevent the geopolymerization reaction, but the presence of illite mineral seems to have a modest contribution in the geopolymerization.
\end{abstract}

\section{Introduction}

It is well known that the Portland cement is the most used hydraulic binder in the world. Yet, it is increasingly causing a high degree of carbon dioxide $\left(\mathrm{CO}_{2}\right)$ emission leading to global warming. Therefore, many research works have been carried out on the synthesis of new hydraulic binder with less energy consumption and less atmospheric generation in order to safeguard the environment $[1,2]$. In 1970, Davidovits has developed a new inorganic polymeric material named "Geopolymer" [3]. This material, with good physical and mechanical properties, has the potential to replace ordinary Portland cement concrete [4]. This new cement is an amorphous, three-dimensional aluminosilicate binder material, whose emission of carbon dioxide is 80 times lower [5].

The geopolymer is obtained by the alkaline attack of aluminosilicate material. Geopolymerization involves an exothermic reaction between the aluminosilicate material (such as metakaolinite $\left(\mathrm{Al}_{2} \mathrm{O}_{3}-2 \mathrm{SiO}_{2}\right)$ ) and a strong alkaline solution $(\mathrm{KOH}, \mathrm{NaOH}$, etc.) at room temperature or slightly above [6].
Recent studies have shown that geopolymer products could also be obtained by the phosphoric acid attack of the activated aluminosilicate material [7-9]. Compared to alkalibased geopolymer, the phosphoric acid-based geopolymers show superior mechanical properties [10].

According to Cao et al. [9], the basic steps of geopolymerization are the dissociation of aluminosilicate material with phosphoric acid and bonding reaction between the low polymeric $\mathrm{P}-\mathrm{O}$ tetrahedral units in phosphoric acid solution and the active $\mathrm{Al}-\mathrm{O}$ structure in metakaolinite granules which adhere to each other, leading to the formation of Al-O-P bonds.

Most of the published research works [7-10] mentioned the use of metakaolin in the synthesis of the phosphoric acidbased geopolymers. But, to the best of our knowledge, no studies have dealt with the synthesis of geopolymers from other aluminosilicate materials. For this reason, the present work considers the synthesis geopolymer from local illitokaolinitic clay. Indeed, Tunisia is among the countries that have many clay fields. Tunisian clays are mainly used in the ceramic industry $[11,12]$ and as pozzolanic materials in cement industry [13]. In a previous work [7] local kaolinitic 
TABLE 1: Chemical composition of used materials.

\begin{tabular}{|c|c|c|c|c|c|c|c|c|c|c|}
\hline & \multicolumn{10}{|c|}{ Compositions (mass\%) } \\
\hline & $\mathrm{SiO}_{2}$ & $\mathrm{Al}_{2} \mathrm{O}$ & $\mathrm{Fe}_{2} \mathrm{O}_{3}$ & $\mathrm{MgO}$ & $\mathrm{Na}_{2} \mathrm{O}$ & $\mathrm{CaO}$ & $\mathrm{K}_{2} \mathrm{O}$ & $\mathrm{SO}_{3}$ & $\mathrm{PO}_{3}$ & LOI \\
\hline Medenine clay & 60.8 & 16.20 & 5.87 & 2.38 & 0.003 & 2.15 & 2.71 & 0.08 & - & 9.16 \\
\hline $\mathrm{H}_{3} \mathrm{PO}_{4}$ & - & - & - & - & - & - & - & - & 85 & - \\
\hline
\end{tabular}

clay from the region of Tabarka was studied as a precursor for the synthesis of phosphoric acid-based geopolymers. The obtained geopolymers presented good mechanical properties. The aim of the present research is to study the effect of the $\mathrm{Si} / \mathrm{P}$ molar ratio on the geopolymerization reaction and its effects on the properties of phosphoric acid-based geopolymers obtained from a local illito-kaolinitic clay from the region of Medenine (south of Tunisia) as a geopolymeric precursor.

\section{Materials and Experimental Methods}

The clay from the South of Tunisia "Medenine" was used as aluminosilicate source. It is characterized by its red color and generally used in ceramic industry. The thermal activation of this clay was performed at $700^{\circ} \mathrm{C}$ for $5 \mathrm{~h}$ in a static bed after sieving at $125 \mu \mathrm{m}$ according to the procedure established by Essaïdi et al. [14] and quenched by air to ambient temperature. The chemical composition of this clay is presented in Table 1. The phosphoric acid used in this study was a commercial phosphoric acid $\mathrm{H}_{3} \mathrm{PO}_{4} 85 \%$ provided by CHEMI-PHARMA and distilled water was used as a solvent.

The geopolymer samples were prepared by mixing the calcined clay powder, distilled water, and phosphoric acid for $1 \mathrm{~min}$ with ultrasonic waves until the paste was homogenous. The liquid/binder ratio was almost constant equal to $20 / 80$. After mixing, the paste specimens were poured into plastic mold $27 \mathrm{~mm}$ in diameter and $54 \mathrm{~mm}$ in height then kept at room temperature for 2 hours before curing at $60^{\circ} \mathrm{C}$ for 24 hours in an oven. The obtained samples were conserved at room temperature for 21 days after demoulding. The obtained phosphoric acid-based geopolymers were examined under different techniques. In order to analyze the geopolymers structure, the samples were immersed in acetone for 24 hours and then dried in an oven at $60^{\circ} \mathrm{C}$ for 5 hours to stop the reaction of geopolymerization [15].

The identification of the synthesized samples is presented in Table 2 . The geopolymer sample is identified as $\mathrm{G}^{x}$, where $x$ is the $\mathrm{Si} / \mathrm{P}$ molar ratio.

The chemical composition of the clay was determined by X-ray fluorescence (ARL 8400; XRF 386 software). The mineralogical composition of the clay and the synthesized geopolymers was identified by X-ray diffraction powder (DRX) with a BRUKER-AXS-D8-Advance powder diffractometer using $\mathrm{Cu} \mathrm{K}$ radiations $\left(\lambda_{k \alpha}=1.5418 \AA\right)$; the analytical range was between 5 and $60^{\circ}(2 \theta)$ at a rate of $1^{\circ} / \mathrm{min}$. Crystallographic phases were identified with the JCPDS cards (Joint Committee Powder Diffraction Standard) and also with the High Score Plus software.
TABLE 2: The formulas of geopolymers samples.

\begin{tabular}{lcccccc}
\hline Formulas & $\mathrm{G}^{3.5}$ & $\mathrm{G}^{3.25}$ & $\mathrm{G}^{3}$ & $\mathrm{G}^{2.75}$ & $\mathrm{G}^{2.5}$ & $\mathrm{G}^{2.25}$ \\
\hline Si/P molar ratio & 3.5 & 3.25 & 3 & 2.75 & 2.5 & 2.25 \\
\hline
\end{tabular}

The infrared spectroscopy was carried out, on mixture added to $\mathrm{KBr}$, to find the different chemical bands in 400$4000 \mathrm{~cm}^{-1}$ spectral range. A Perkin Elmer spectrum BX apparatus was used.

The phosphoric acid-based geopolymers samples were mechanically characterized by using LLOYD LR 50K PLUS device which is equipped with compressive test units. The testing rate used is $0.2 \mathrm{~mm} / \mathrm{min}$. Tests were performed on cylindrical samples having a diameter of $27 \mathrm{~mm}$. Sample surfaces were previously polished to ensure the best surface quality (parallelism and planarity). All values of the compressive strength reported in this study are mean values over five tests under the same conditions.

\section{Results and Discussion}

3.1. Raw Materials Characterization. The chemical composition of the Tunisian clay (Medenine clay) used during this study is presented in Table 1. It is clear from these results that the weight percentage of silicon oxides is relatively high $\left(\mathrm{SiO}_{2}\right.$ $=60.8$ mass $\%$ ), probably indicating the presence of free silica and/or clay mineral type $2: 1$. In addition, this clay contains a considerable percentage of potassium $\left(\mathrm{K}_{2} \mathrm{O}=2.71\right.$ mass $\left.\%\right)$, suggesting the presence of illite mineral. The high percentage of iron oxide $\left(\mathrm{Fe}_{2} \mathrm{O}_{3}=5.87\right.$ mass\%) is responsible for the characteristic red color of the clay. Finally, Medenine clay contains some $\mathrm{CaO}$ and $\mathrm{MgO}$, which are probably related to the presence of dolomite [14].

The examination of the X-ray pattern of Medenine clay (Figure 1) indicates the presence of kaolinite and illite minerals, which are associated with nonclayey minerals such as quartz, muscovite, dolomite, gypsum, and hematite. This result is in accordance with those obtained by fluorescence $\mathrm{X}$. Moreover, the comparison between the X-ray patterns of Medenine clay before and after calcination shows that all diffraction peaks related to kaolinite and gypsum disappeared after calcinations at $700^{\circ} \mathrm{C}$ for 5 hours, which proves the transformation of kaolinite into metakaolinite as well as the dehydration of gypsum. In addition, the peaks related to quartz, muscovite, illite, and hematite persisted after heat treatment. The persistence of illite and hematite has already been reported by $\mathrm{He}$ et al. [16] and Hosseini-Zori et al. [17], respectively. 
TABLE 3: The principal IR bands and their corresponding species of raw and calcined clay.

\begin{tabular}{|c|c|c|c|}
\hline \multicolumn{2}{|c|}{ Medenine clay } & \multicolumn{2}{|c|}{ Calcined Medenine clay } \\
\hline Wavenumber $\left(\mathrm{cm}^{-1}\right)$ & Corresponding species & Wavenumber $\left(\mathrm{cm}^{-1}\right)$ & Corresponding species \\
\hline 3656,3698 & Hydroxyl groups $(\mathrm{OH})$ of kaolinite & - & - \\
\hline 3624 & Hydroxyl groups $\mathrm{OH}$ of illite & 3624 & $\mathrm{Al}-\mathrm{OH}$ of illite \\
\hline 3434 & $\mathrm{OH}$ of water & - & - \\
\hline 1648 & $\mathrm{H}-\mathrm{O}-\mathrm{H}$ of water & - & - \\
\hline $1000,1036,1005$ & $\mathrm{Si}-\mathrm{O}$ & 1034 & $\mathrm{Si}-\mathrm{O}$ \\
\hline 470 & $\mathrm{Si}-\mathrm{O}$ & 480 & $\mathrm{Si}-\mathrm{O}$ \\
\hline 789,778 & Doublet of quartz & 789,778 & Doublet of quartz \\
\hline 536,754 & $\mathrm{Al}^{\mathrm{VI}}-\mathrm{OSi}, \mathrm{Al}^{\mathrm{IV}}-\mathrm{OSi}$ of illite and kaolinite & - & - \\
\hline 694 & Si-O-Si of quartz & 694 & Si-O-Si of quartz \\
\hline 912 & Al-OH of kaolinite & - & - \\
\hline
\end{tabular}
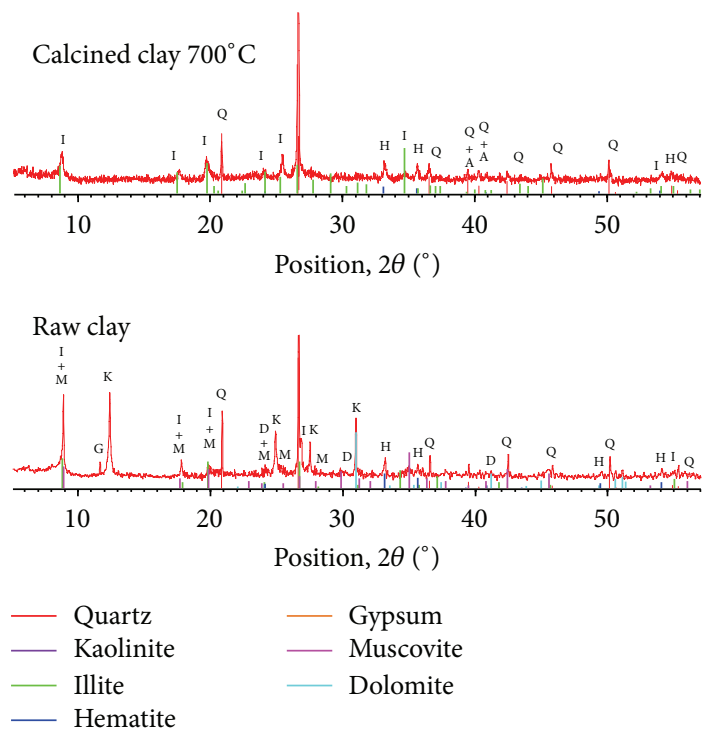

FIGURE 1: XRD patterns of raw and calcined Medenine clay at $700^{\circ} \mathrm{C}$ for 5 hours. Q: quartz (00-046-1045), K: kaolinite (00-001-0527), I: illite (00-024-0495), H: hematite (00-024-0072), G: gypsum (04009-3817), M: muscovite (00-001-1098), and D: dolomite (01-0751655).

The differential thermal and thermogravimetric analysis (DTA-TG) of Medenine clay were already reported by Essaïdi et al. [14]. The thermograms have shown the appearance of five phenomena, four of which are endothermic and are as follows: the first one is related to the elimination of the free water at $T<100^{\circ} \mathrm{C}$, the second one, at $T=115^{\circ} \mathrm{C}$, resulted from the dehydration of gypsum, the third one occurring at approximately $480^{\circ} \mathrm{C}$ is attributed to the structural dehydroxylation of kaolinite and the formation of the amorphous phase, metakaolinite, and the fourth phenomenon at $700^{\circ} \mathrm{C}$ is correlated to the decarbonation of dolomite. In addition, an exothermic phenomenon at $\sim 970^{\circ} \mathrm{C}$ may be attributed to the structural reorganization of metakaolinite.

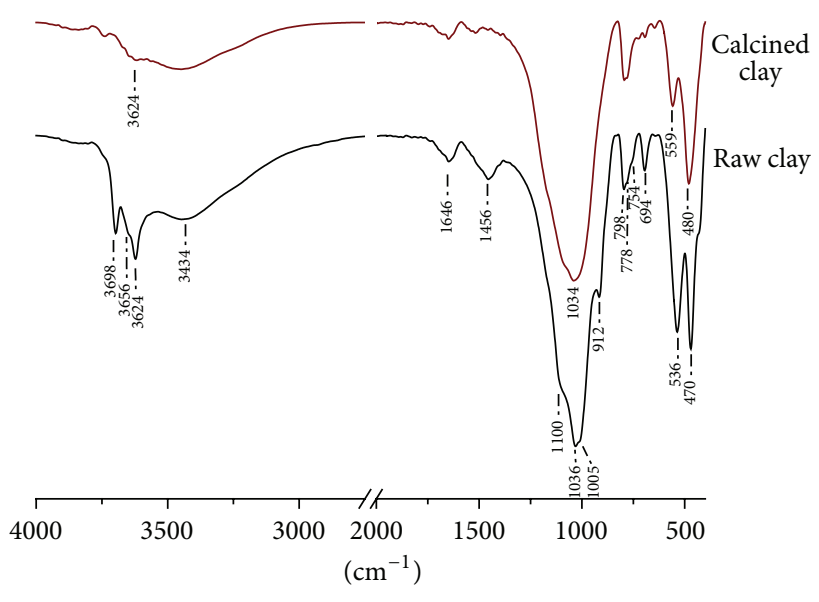

FIGURE 2: FTIR spectra of raw and calcined clay.

The infrared spectra of the raw and calcined clay are presented in Figure 2. The first spectrum indicates the presence of the characteristic bands of kaolinite and illite. The wavenumber of principal bands and their corresponding species are given in Table 3.

The characteristic bands of $3698,3656,3624$, and $3434 \mathrm{~cm}^{-1}$ correspond to the stretching vibration of the hydroxyl groups $(\mathrm{OH})$ of kaolinite and illite [18]. The other bands at $1005,1036,1100$, and $470 \mathrm{~cm}^{-1}$ are those of Si-O bonds $[18,19]$. In addition, the band located at $912 \mathrm{~cm}^{-1}$ attributed to the deformation vibration of $\mathrm{Al}-\mathrm{OH}$ [19], and the bands at 754 and $536 \mathrm{~cm}^{-1}$ arise from the deformation vibrations of $\mathrm{Al}^{\mathrm{IV}}-\mathrm{OSi}$ and $\mathrm{Al}^{\mathrm{VI}}$-OSi $[18,19]$. The presence of a doublet at 798 and $778 \mathrm{~cm}^{-1}$ and a single located at $694 \mathrm{~cm}^{-1}$ is attributed to the quartz vibrations [20]. This result is in accordance with that of XRD patterns.

The comparison of the clay IR spectra before and after calcination at $700^{\circ} \mathrm{C}$ in the spectral range between 400 and $4000 \mathrm{~cm}^{-1}$ shows the disappearance of $\mathrm{O}-\mathrm{H}$ bands attributed to kaolinite and the reduction of those of illite $\left(3624 \mathrm{~cm}^{-1}\right)$. 

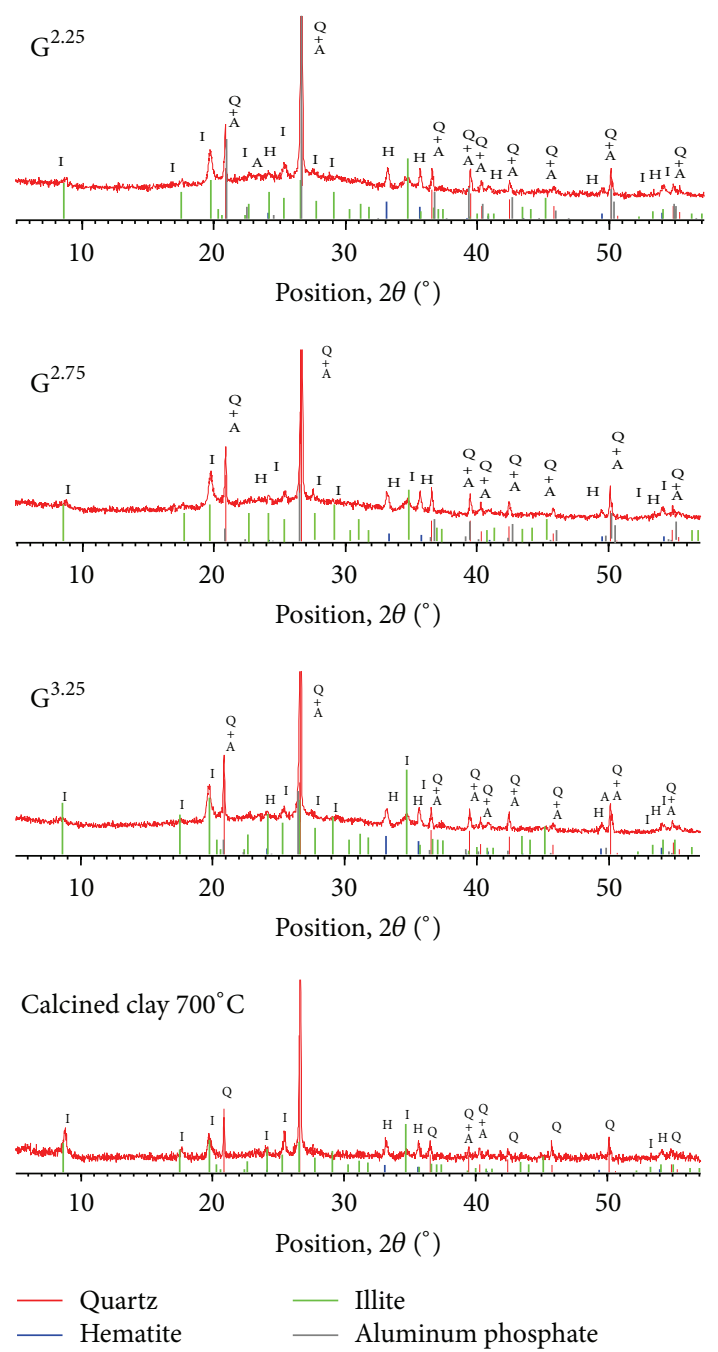

FIGURE 3: X-ray patterns of calcined clay and the obtained geopolymers $\mathrm{G}^{x}$ with different $\mathrm{Si} / \mathrm{P}$ molar ratios (21 curing ages). Q: quartz (00-046-1045), H: hematite (00-024-0072), I: illite (00-024-0495), and A: aluminum phosphate (00-084-0853).

We also note that, after calcination at $700^{\circ} \mathrm{C}$, between 1200 and $800 \mathrm{~cm}^{-1}$, the various bands attributed to illite and kaolinite have been transformed into $\mathrm{Q}^{4}$ to $\mathrm{Q}^{1}$ silicates, which are in accordance with the effects of temperature [19]. Thus, we come to the conclusion that the calcination temperature at $700^{\circ} \mathrm{C}$ is sufficient to transform the kaolinite into metakaolinite, but for the illite, this temperature is not enough to transform this mineral to an amorphous material.

3.2. Geopolymers Characterization. The mineralogical compositions of geopolymers samples determined by X-ray diffraction are shown in Figure 3. The XRD analysis of all geopolymers samples with different molar ratios proves the presence of quartz, illite, and hematite, which already exist in calcined clay. In addition, the XRD patterns of these geopolymer samples prove the presence of a diffuse halo between 25 and $35^{\circ}$ characteristic of an amorphous material. When the $\mathrm{Si} / \mathrm{P}$ molar ratio decreases, that is, when the amount of phosphoric
TABLE 4: The semiquantitative X-ray diffraction of the crystalline phases in the obtained geopolymers.

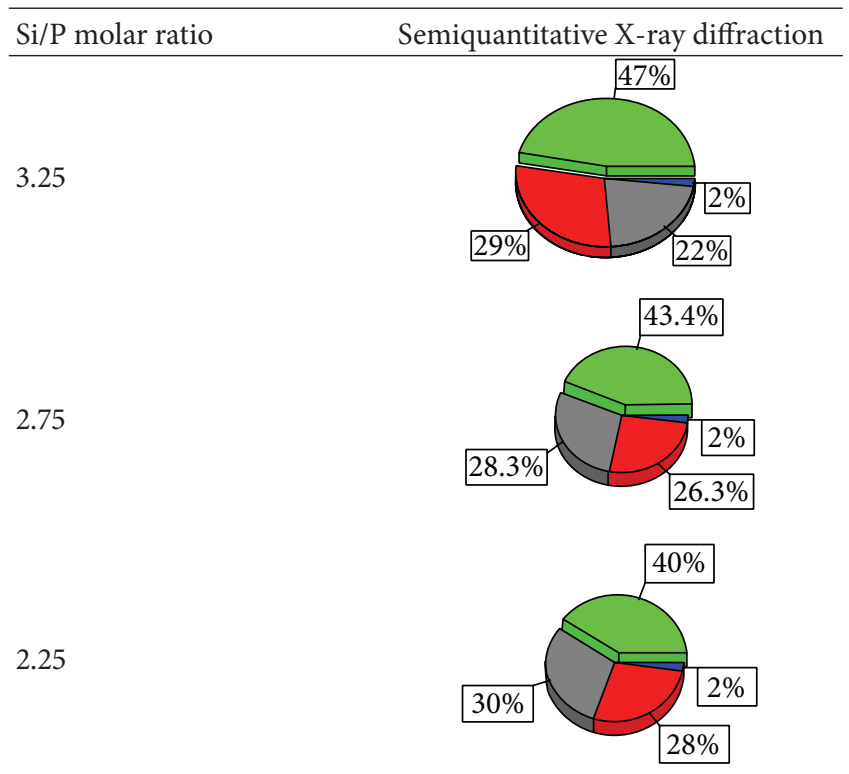

Green: illite, red: quartz, blue: hematite, and gray: aluminum phosphate.

acid increases, the halo diffuse intensity increases. This could be explained by the fact that when the amount of phosphoric acid increases, the dissolution step in geopolymerization process increases. Furthermore, the XRD analysis proves also the presence of new crystalline phases such as aluminum phosphate, which is formed during geopolymerization.

The semiquantitative X-ray analysis (Table 4) shows that the iron dioxide percentage (hematite) is the same $\left(\% \mathrm{Fe}_{2} \mathrm{O}_{3}=\right.$ 2) whatever the $\mathrm{Si} / \mathrm{P}$ molar ratio is $(2.25,2.75$, or 3.5$)$. This may be explained by the noncontribution of hematite in the geopolymerization. Therefore, the hematite structure is not destroyed by the phosphoric acid and iron does not penetrate into the structure of geopolymers. In addition, the illite amount is relatively reduced $(47>43>40 \%$ ) when the $\mathrm{Si} / \mathrm{P}$ molar ratio decreases, which indicates a slight contribution of illite in the geopolymerization reaction. This could be explained by the fact that a calcination temperature of $700^{\circ} \mathrm{C}$ is not sufficient to transform the illite mineral to an amorphous material, potentially reactive with phosphoric acid. As for the percentage of aluminum phosphate, it increases $(22<28<30 \%)$ when the Si/P molar ratio decreases. This indicates the evolution of the dissolution phase during the geopolymerization process.

The infrared spectra of the phosphoric acid, calcined clay, aluminum phosphate, and synthesized geopolymers at different $\mathrm{Si} / \mathrm{P}$ molar ratios are presented in Figure 4 . The infrared spectra of all geopolymers samples indicate (i) the disappearance of the metakaolinite bands $\left(480\right.$ and $559 \mathrm{~cm}^{-1}$ ), (ii) the persistence of illite bands $\left(3624 \mathrm{~cm}^{-1}\right)$, and (iii) the appearance of new bands which are related to other species. The appearance of the bands characteristic of stretching and deformation vibration of $\mathrm{O}-\mathrm{H}$ and $\mathrm{H}-\mathrm{O}-\mathrm{H}$ groups at 1648 and $3395 \mathrm{~cm}^{-1}$, respectively, indicates the presence of free water molecules. The amount of this water seems to increase when 


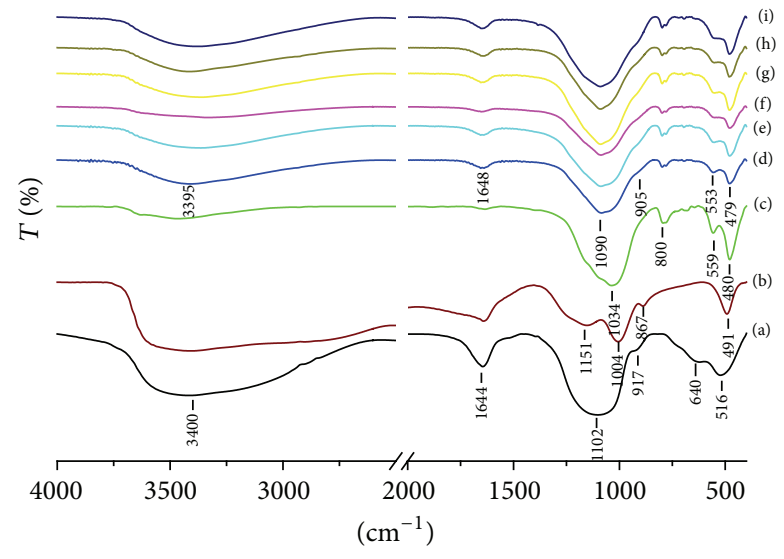

Figure 4: Infrared spectra of calcined Medenine clay at $700^{\circ} \mathrm{C}$, phosphoric acid $85 \%$, aluminum phosphate, and geopolymers at different molars ratios $\mathrm{Si} / \mathrm{P}\left(\mathrm{G}^{x}\right)$. (a) $\mathrm{AlPO}_{4}$, (b) $\mathrm{AP}$ (85\%), (c) calcined clay $700^{\circ} \mathrm{C}$, (d) $\mathrm{G}^{3.5}$, (e) $\mathrm{G}^{3.25}$, (f) $\mathrm{G}^{3}$, (g) $\mathrm{G}^{2.75}$, (h) $\mathrm{G}^{2.5}$, and (i) $\mathrm{G}^{2.25}$.

the molar ratio $\mathrm{Si} / \mathrm{P}$ increases. Furthermore, the band at $1034 \mathrm{~cm}^{-1}$ in the spectrum of calcined clay is shifted about $56 \mathrm{~cm}^{-1}$ to larger wavenumber, after geopolymerization reaction. This result proves that a change in the microstructure occurred during the geopolymerization reaction and led to the formation of new products with a microstructure different from that of calcined clay. According to Figure 4, the large band at $1090 \mathrm{~cm}^{-1}$ for geopolymers spectra is the result of the linked bands between $\mathrm{Si}-\mathrm{O}$ symmetrical vibration, $\mathrm{P}-\mathrm{O}$ vibration, and Al-O bands. So the obtained products are $\mathrm{Si}-$ O-Al-O-P oligomers. Moreover, after the geopolymerization reaction, the band located at $559 \mathrm{~cm}^{-1}$ in the spectrum of calcined clay attributed to $\mathrm{Si}-\mathrm{O}-\mathrm{Al}$ shifted to $553 \mathrm{~cm}^{-1}$. It is clear that its intensity increases when the amount of phosphoric acid increases. It is noteworthy that the shift may be the consequence of the partial replacement of $\mathrm{SiO}_{4}$ tetrahedron by $\mathrm{PO}_{4}$ during the process, which suggests a change in the local chemical environment. However, when the molar ratio $\mathrm{Si} / \mathrm{P}$ decreases, that is, when the amount of phosphoric acid increases, the intensity of the bands located at $479 \mathrm{~cm}^{-1}$ in the infrared spectra of geopolymers increases. This would probably be explained by the consumption of $\mathrm{Si}-\mathrm{O}$ monomers and the formation of oligomers type Si-O$\mathrm{P}$. In addition, the appearance of a new band at $905 \mathrm{~cm}^{-1}$ for all geopolymers samples indicates the incorporation of $\mathrm{P}-\mathrm{O}$ band in the structure of geopolymers. Finally, a slight modification took place for the intensity of the shoulder of illite located around $830 \mathrm{~cm}^{-1}$. This indicates the modest contribution of the illite present in the starting calcined clay to geopolymerization process. These results are in accordance with those obtained by X-ray diffraction.

The results of the mechanical properties of geopolymers after 21 curing days are presented in Figure 5. The latter shows that when the $\mathrm{Si} / \mathrm{P}$ molar ratio decreases, the compressive strength increases until a maximum value $(37 \mathrm{MPa})$ when the molar ratio $(\mathrm{Si} / \mathrm{P})$ equals 2.75 . Beyond this ratio, the mechanical strength decreases. For higher Si/P molar ratios,

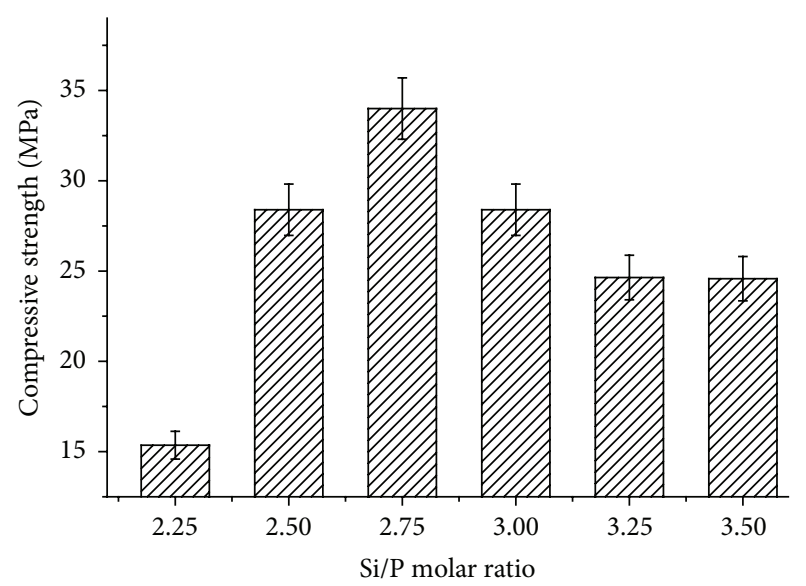

FIGURE 5: Compressive strength evolution of the phosphoric acidbased geopolymers $\mathrm{G}^{x}$ at 21 curing days for different $\mathrm{Si} / \mathrm{P}$ molar ratio.

corresponding to relatively small amount of phosphoric acid, the mechanical strength is low because the dissolution phase is not completed. This is due to the deficiency in the amount of the phosphoric acid. For the molar ratio $\mathrm{Si} / \mathrm{P}$ $=2.75$, the compressive strength is maximum, because the amount of phosphoric acid is sufficient enough to complete the dissolution step. For this $\mathrm{Si} / \mathrm{P}$ ratio, the charge balance is assured because the corresponding numerical ratio $\mathrm{AlO}_{4} / \mathrm{PO}_{4}=1$ [9]. For lower $\mathrm{Si} / \mathrm{P}$ molar ratios, the large amounts of phosphoric acid lead to an excess in $\mathrm{PO}_{4}{ }^{3-}$ which improves the dissolution of the geopolymerization process to be more disordered. Consequently, the mechanical properties decrease due to the unbalanced charges [7].

These results are in accordance with those obtained by the SEM (Figure 6) which indicates that the structure of the obtained geopolymers becomes denser, when the Si/P molar ratio decreases from 3.25 to 2.75 . For lower Si/P molar ratio, the structure is less dense (Figure 6).

\section{Conclusion}

The properties of the phosphoric acid-based geopolymers obtained through using calcined illito-kaolinitic clay at $700^{\circ} \mathrm{C}$ sieved at $125 \mu \mathrm{m}$ as an aluminosilicate precursor for making geopolymers are affected by the variation of the Si/P molar ratios. The main findings of this study are the following:

(i) When the $\mathrm{Si} / \mathrm{P}$ molar ratio decreases, the diffuse hallo in the XRD geopolymer spectra, that is, the amorphous phase content, increases.

(ii) In addition to the amorphous phase, geopolymer XRD analyses show the presence of $\mathrm{AlPO}_{4}$ as a product of geopolymerization reaction.

(iii) The infrared spectra of geopolymers samples show that the geopolymerization product has a polymeric $\mathrm{Si}-\mathrm{O}-\mathrm{Al}-\mathrm{O}-\mathrm{P}$ structure.

(iv) The contribution of illite in the geopolymerization process is relatively low. 

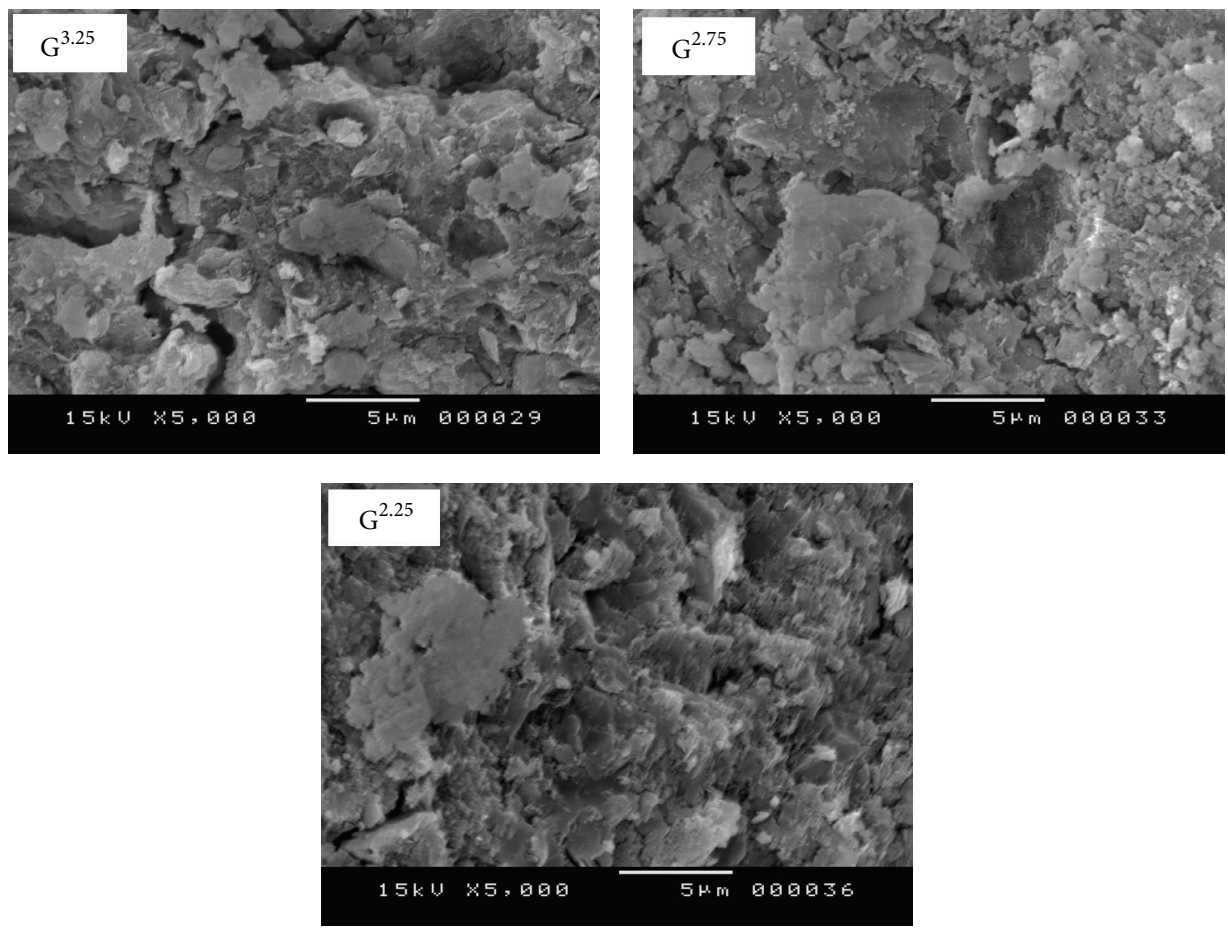

FIGURE 6: SEM microcrographs of phosphoric acid-based geopolymers at different Si/P molar ratios.

(v) The mechanical strength of geopolymer attains a maximum (37 MPa) for Si/P molar ratio equal to 2.75, which corresponds to a molar ratio $\mathrm{Al} / \mathrm{P}=1$.

\section{Competing Interests}

The authors declare that they have no competing interests.

\section{References}

[1] V. M. Malhotra, "Introduction: sustainable development and concrete technology," Concrete International, vol. 24, no. 7, 22 pages, 2002.

[2] P. K. Mehta, "Reducing the environmental impact of concrete," ACI Concrete International, vol. 23, no. 10, pp. 61-66, 2001.

[3] J. Davidovits, "Mineral polymers and methods of making them," US Patent 1982 No 4472, 1993.

[4] W. K. W. Lee and J. S. J. Van Deventer, "The effect of ionic contaminants on the early-age properties of alkali-activated fly ash-based cements," Cement and Concrete Research, vol. 32, no. 4, pp. 577-584, 2002.

[5] K. Daniel, J. Sanjayan, and K. Sagoe-Crentsil, "The behaviour of geopolymer paste and concrete at elevated temperatures," in Proceedings of the International Conference on Pozzolan, Concrete and Geopolymer, pp. 105-118, Khon Kaen, Thailand, May 2006.

[6] J. Davidovits, "Geopolymers: man-made rock geosynthesis and resulting development of very early high strength cement," Journal of Materials Education, vol. 16, pp. 91-139, 1994.

[7] S. Louati, W. Hajjaji, S. Baklouti, and B. Samet, "Structure and properties of new eco-material obtained by phosphoric acid attack of natural Tunisian clay," Applied Clay Science, vol. 101, pp. 60-67, 2014.

[8] H. Douiri, S. Louati, S. Baklouti, M. Arous, and Z. Fakhfakh, "Structural, thermal and dielectric properties of phosphoric acid-based geopolymers with different amounts of $\mathrm{H}_{3} \mathrm{PO}_{4}$," Materials Letters, vol. 116, pp. 9-12, 2014.

[9] D. Cao, D. Su, B. Lu, and Y. Yang, "Synthesis and structure characterization of geopolymeric material based on metakaolinite and phosphoric acid," Journal of the Chinese Ceramic Society, vol. 33, no. 11, pp. 1385-1389, 2005.

[10] L. Le-ping, C. Xue-min, Q. Shu-heng, Y. Jun-li, and Z. Lin, "Preparation of phosphoric acid-based porous geopolymers," Applied Clay Science, vol. 50, no. 4, pp. 600-603, 2010.

[11] M. Krichen, S. Baklouti, and Bouaziz, "Mineralogy and firing behavior of a clay raw material from Wislatiya (Tunisia)," Silicates Industriels, vol. 73, no. 9-10, pp. 185-190, 2008.

[12] M. Krichen, F. Ben Ayed, S. Baklouti, J. Bouaziz, and J.-P. Bonnet, "Mineralogy and sintering behaviour of a clay mineral from Bir Mcherga (Tunisia)," Silicates Industriels, vol. 74, no. 1-2, pp. 41-46, 2009.

[13] A. Chakchouk, B. Samet, and T. Mnif, "Study on the potential use of Tunisian clays as pozzolanic material," Applied Clay Science, vol. 33, no. 2, pp. 79-88, 2006.

[14] N. Essaïdi, B. Samet, S. Baklouti, and S. Rossignol, "Feasibility of producing geopolymers from two different Tunisian clays before and after calcination at various temperatures," Applied Clay Science, vol. 88-89, pp. 221-227, 2014.

[15] S. Alonso and A. Palomo, "Calorimetric study of alkaline activation of calcium hydroxide-metakaolin solid mixtures," Cement and Concrete Research, vol. 31, no. 1, pp. 25-30, 2001.

[16] C. He, E. Mokovicky, and B. Osbaeck, "Pozzolanic reactions of six principle clay minerals: activation, reactivity assessments 
and technological effects," Applied Clay Science, vol. 9, pp. 337354, 1995.

[17] M. Hosseini-Zori, E. Taheri-Nassaj, and A. R. Mirhabibi, "Effective factors on synthesis of the hematite-silica red inclusion pigment," Ceramics International, vol. 34, no. 3, pp. 491-496, 2008.

[18] V. C. Farmer, "The layer silicates," in The Infrared Spectra of Minerals, V. C. Farmer, Ed., pp. 331-363, The Mineralogical Society, London, UK, 1974.

[19] C. Bich, Contribution à l'étude de l'activation thermique du kaolin: évolution de la structure cristallographique et activité pouzzolanique [Ph.D. thesis], Institut National des Sciences Appliquées de Lyon, Lyon, France, 2005.

[20] M. Criado, A. A. Fernández-Jiménez, and A. Palomo, "Alkali activation of fly ash: effect of the $\mathrm{SiO}_{2} / \mathrm{Na}_{2} \mathrm{O}$ ratio: part I: FTIR study," Microporous and Mesoporous Materials, vol. 106, no. 1-3, pp. 180-191, 2007. 

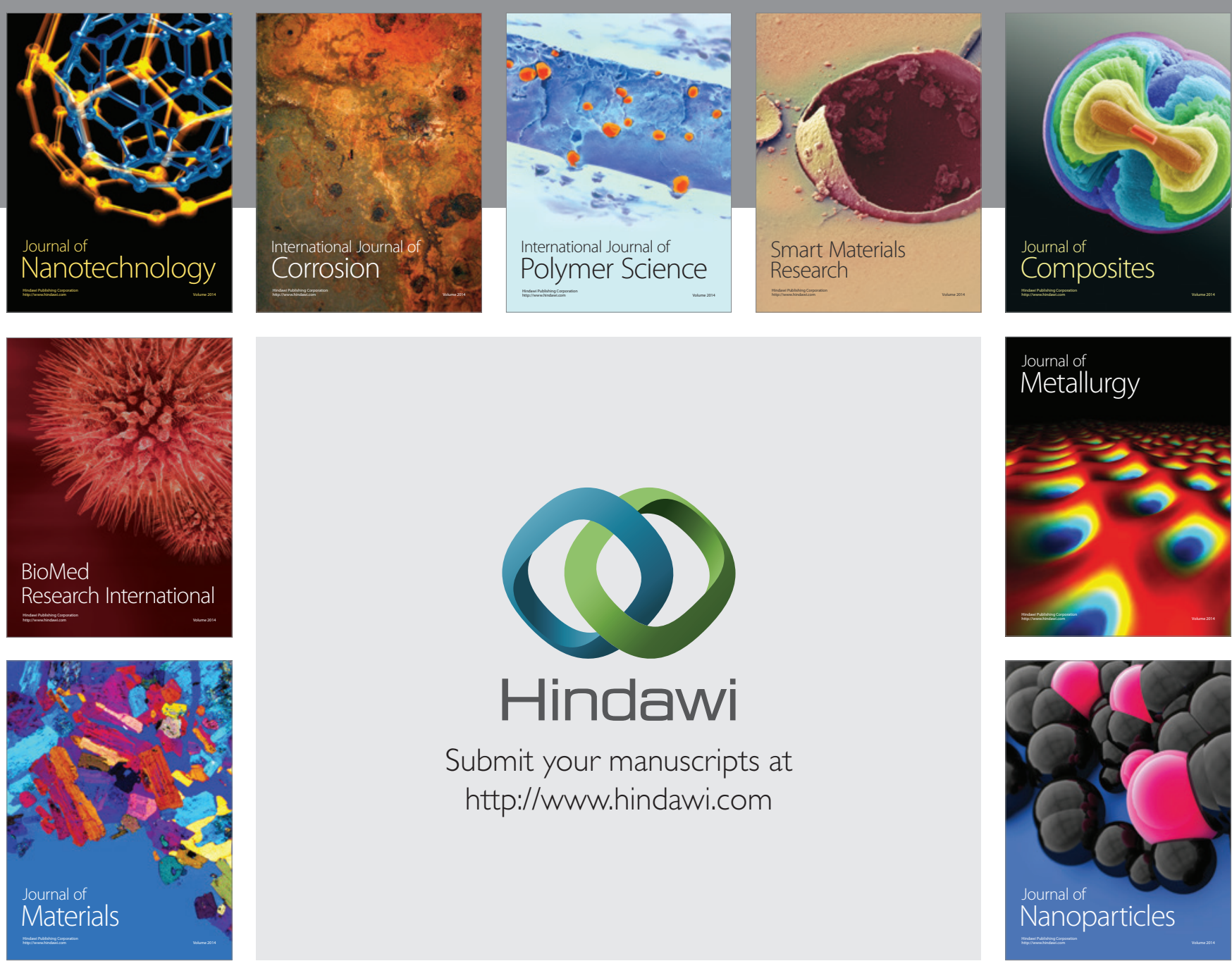

\section{Hindawi}

Submit your manuscripts at

http://www.hindawi.com

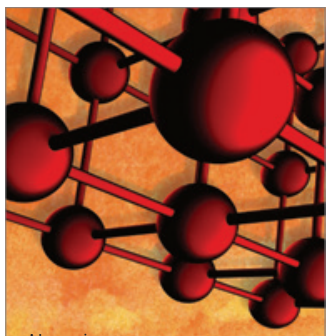

Materials Science and Engineering
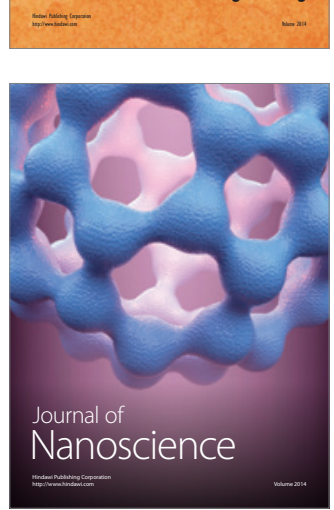
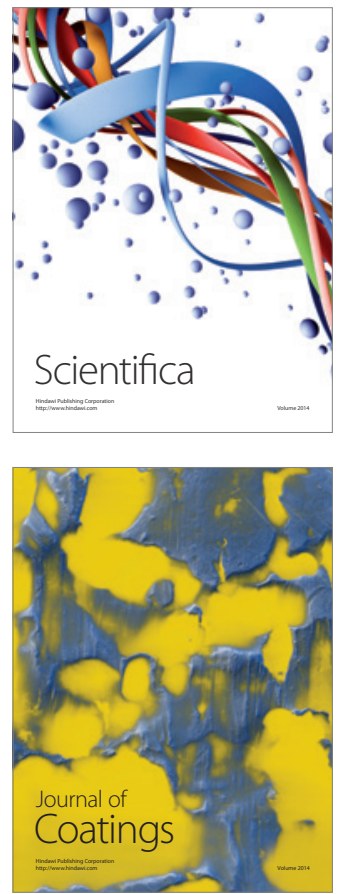
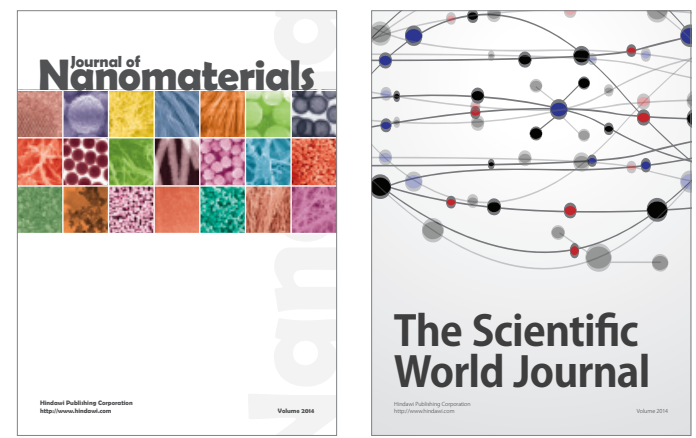

The Scientific World Journal
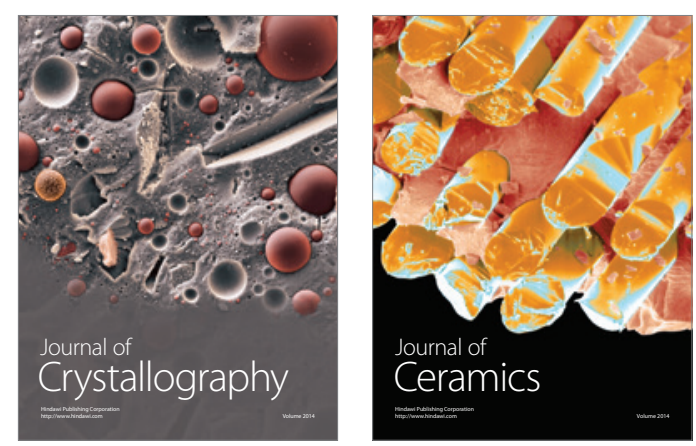
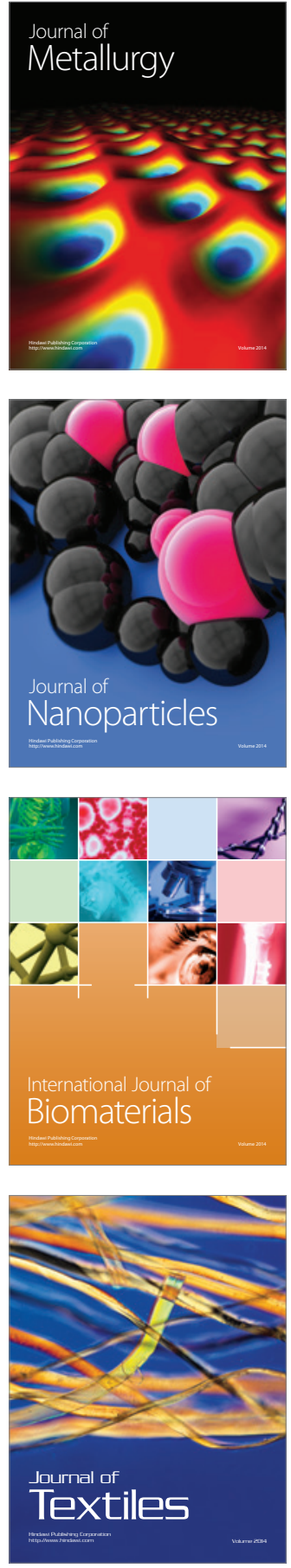